\title{
$\left.15\right|^{2}$ FIRST INTERNATIONAL CONGRESS OF BIOCHEMISTRY
}

$T$ HE First International Con ress of Biochemistry, initiated by the (Pritis') Biochemical Society, which was held in Catp oxige during August 19-25, was opened in the Sen te Hoyse pothe University by the president, Prff. A. C. Chibn ll Viscount Addison, Lord Privy Sed, welcom the members on behalf of the Government, and D. E. C. Raven, the vicechancellor, re behalf of the University.

More than 1,700 members attended the Congress, rewrositing forty-two different countries. In his opening speech, Prof. Chibnall recalled the work of the Société de Chimie Biologique in organising since 1927 eight congresses for French-speaking biochemists and thus paving the way for the present International Congress.

On August 20 the University of Cambridge held a special congregation to confer the degree of doctor of science (honoris causa) on each of the following: Viscount Addison (U.K.), Prof. C. F. Cori (U.S.A.), Sir Charles Harington (U.K.), Prof. K. LinderstrømLang (Denmark), Prof. A. W. K. Tiselius (Sweden) and Prof. J. Trefouël (France).

It was inevitable that, during the week, thoughts should often turn to the late Sir Frederick Gowland Hopkins, who was for fifty years professor of biochemistry in Cambridge and who may be considered the founder of biochemistry in Britain. In Prof. Chibnall's opening address and on many other occasions, tributes were paid to his work and personality. A copy of the book "Hopkins and Biochemistry", specially prepared for this occasion, was presented to each member of the Congress.

The Committee of the Congress had called together an ad hoc International Committee, which drafted and adopted the following resolutions :

(1) That after careful consideration of the invitations received from both France and Italy, it is unanimously agreed that the invitation of the Société de Chimie Biologique for the holding of the next International Congress of Biochemistry in Paris in $\mathbf{1 9 5 2}$ be accepted with gratitude.

(2) That an International Committee for Biochemistry be now set up. (This committee is composed of eighteen members representing Australia, Belgium, Canada, France, India, Italy, Netherlands, Poland, Scandinavia, Switzerland, South America, the United Kingdom, and U.S.A., with two places kept for Russian members to be nominated by the appropriate authority. Chairman, Sir Charles Harington ; secretary, Prof. K. Linderstrøm-Lang.)

(3) That this Committee be instructed to approach the International Council of Scientific Unions with a request for recognition as the international body representative of biochemistry, with a view to the formal constitution of an International Union of Biochemistry, as soon as possible.

These resolutions were passed unanimously by the members of the Congress at the closing meeting.

The enjoyable conditions in which the Congress was held and the smooth running of the prganisation was due in the main to the work (with all their helpers) of
Dr. E. Baldwin, Prof. F. Dickens and Lieut.-Colone E. C. Griffin. A great debt of gratitude is owing $t$ these three.

The scientific proceedings of the Congress wer divided into twelve sections, running simultaneously (I) Animal Nutrition and General Metabolism (II) Microbiological Chemistry; (III) Enzymes anc Tissue Metabolism; (IV) Proteins; (V) Clinica Biochemistry; (VI) Structure and Synthesis o: Biologically Important Substances; (VII) Cyto. chemistry; (VIII) Biological Pigments: Oxygen Carriers and Oxidizing Catalysts; (IX) Hormones and Steroids; (X) Chemotherapy and Immuno. chemistry ; (XI) Plant Biochemistry ; (XII) Indus. trial Fermentations. Besides these meetings, three Congress lectures were held. These were given before very large audiences by Prof. C. F. Cori (on "Influence of Hormones on Enzymatic Reactions"); by Prof. M. Florkin (on "Biochemical Aspects of some Biological Concepts") and by Sir Robert Robinson (on "Tryptophan and its Structural Relatives").

The section meetings covered a very wide field and comprised some five hundred communications. The following account of necessity touches upon only a small selection.

In Section I a discussion on dietary factors leading to liver damage (opened by Prof. G. R. Cameron) showed that there are good grounds for hope that these studies of artificially produced liver changes in animals may throw light on human hepatic injury. Two sessions were held on the anæmias. E. Lester Smith outlined methods of isolation of vitamin $B_{12}$ and $K$. Folkers discussed its chemical and physical properties. Mary S. Shorb, the first successfully to apply the procedure of microbiological assay to this vitamin, gave an account of work in this field. C. C. Ungley and M. M. Wintrobe considered clinical aspects of the role of dietary factors in anæmia. The significance of trace metals in wasting diseases of domestic animals was discussed by D. P. Cuthbertson.

In Section II some new aspects of the adaptive enzyme question were discussed. F. Bernheim described the very rapid acquirement by avirulent strains of tubercle bacillus of the power to oxidize benzoic acid. M. Pollock reported that the adaptive penicillinase of $B$. cereus persists for seven or eight generations when the organism is grown in absence of penicillin. The adaptive enzyme nitratase may be acquired by coliform organisms in absence of nitrate if a complete mixture of amino-acids (casein hydrolysate) is supplied. J. De Ley showed the other side of this picture when he described the preferential loss of adaptive enzymes in organisms grown in nitrogen. deficient media, the constitutive enzymes maintaining much of their activity.

P. C. Lichtstein reported that the prosthetic group of aspartic deaminase is probably a complex of biotin containing also adenylic acid. L. D. Wright described the preparation of a few milligrams of a crystalline biotin complex from four tons of yeast; this material activated the aspartic deaminase system. K. C. Winkler described non-competitive antagonists of sulphanilamide, and D. D. Woods discussed the 
interrelationship of $p$-aminobenzoic acid and pteroylglutamic acid with regard to sulphanilamide action. P. D. Mitchell and J. M. Moyle, using Staph. aureus, have shown that the first effect of penicillin upon metabolism (occurring very rapidly) is an upset in purine nucleotide metabolism.

In Section III a discussion on acetyl choline esterase centred largely around the specificity and characterization of this important enzyme (Mendel, Augustinsson, Whitaker, 'J. A. Cohen, Nachmansohn, Feldberg and Rossiter taking part). F. Lipmann contributed observations on the uncoupling by dinitrophenol of oxidation and phosphorylation and discussed the mechanism of generation of phosphate bond energy. D. B. MeNair Scott described the use of paper chromatograms to follow the products of the TPN-catalysed oxidation of glucose-6-phosphate by enzyme preparations from yeast and bacteria. Two communications were concerned with attempts to penetrate the mechanism of protein synthesis-that of Ellis, Gillespie and Lindley on a study of the wool root, and that given by Borsook on the incorporation of carbon-14 labelled amino-acids into the proteins of liver, marrow cells and diaphragm. Interesting studies were described on the effects of emotional excitement on brain metabolism (Richter) and of mustard gas and X-rays on bone marrow metabolism (Lutwak-Mann); on hexokinase and phosphatase activity of intestinal mucosa homogenates in relation to sugar absorption (Hele); and on the formation of long-chain fatty acids from acetate in the mammary gland (Folley and French). A session on developmental biochemistry was held, to which contributions were made by Lundblad, Agrell, ten Cate and Niemierko.

In the section on proteins, perhaps the most lively discussion was stimulated by A. Rothen's communication on postulated long-range forces (between antibody and antigen or between enzyme and substrate) acting through a 'screen' of material, for example, polyvinyl chloride. C. Weibull showed that the flagella of the two bacterial species so far investigated (Proteus vulgaris and Bacillus subtilis) consist almost entirely of a single protein. Fourteen constituent amino-acids have been identified, but tryptophan, cystine (and cysteine), histidine and hydroxyproline are absent. X-ray diffraction studies (showing the $\alpha$-pattern) and electron microscope studies have been made The separation and quantitative determination of amino-acids, using chromatography on starch columns (S. Moore and W. H. Stein), and resinous ion-exchangers (Partridge) and microbiological methods (M. S. Dunn) were discussed. By Moore and Stein's method, only $5 \mathrm{mgm}$. of protein is needed for an analysis of constituent amino-acids. F. Sanger described the extension of his method of end-group assay with $1: 2: 4$-fluorodinitrobenzene to the separation of peptides by partial hydrolysis. This had made possible the identification of peptide sequences extending from the terminal residue. Desnuelle discussed the importance of the 'nature' and the 'position' of the peptide bond in determining its rupture by acid and by crystalline pepsin.

In Section V, R. Nicolaysen discussed the effects of vitamin $\mathrm{D}$ and of phytic acid on calcium absorption as studied in his isolated-loop technique with rats. Sir Edward Mellanby considered the distribution of phytase and the relation of vitamin $D$ to phytase activity. Sessions were included on liver function, kidney function, the sprue syndrome and clinical aspects of protein metabolism.
In Section VI, E. Chargaff described accurate chromatographic methods for the determination of the building units of ribose and deoxyribose nucleic acids. A. R. Todd described two different methods of synthesis of adenosine triphosphate, one of which raises the possibility of its existence in a cyclic form. G. B. Brown gave a communication on tracer studies for the elucidation of pathways of nucleic acid utilization and synthesis in animals. O. Kamm gave an account of the purification and properties of the anti-diuretic hormone of the posterior pituitary, and F. Lipmann of the chemistry and functions of co-enzyme A.

L. Zechmeister showed how molecular shape and stereochemistry control the provitamin-A activity of the various carotenoid pigments of part-cis configuration. Considerable discussion was stimulated by two papers on melanin formation (by $\mathbf{H}$. Mason and J. Harley-Mason) and by E. Schlittler's novel and well-founded suggestion that picrotoxinin is best formulated as containing a nine-membered carbon ring system.

In the cytochemistry section the paper by $P$. C. Koller on cytological criteria in the interpretation of effects of mitotic poisons led to an animated discussion. H. Holter described his results on the distribution of proteolytic enzymes in amœbæ, and D. Richter on the localization of phosphatases, carbonic anhydrase and true choline esterase in cells of the cerebral cortex. P. Mandel found that in prolonged protein starvation there is a great loss of ribose nucleic acid, whereas deoxyribose nucleic acid remains constant; in muscle atrophy after nerve section the same thing occurs. A. Chantrenne gave an account of the work of Brachet, Jeener and Chantrenne on the separation, in a continuous series of sizes, of protoplasmic particles. The smallest contain the highest amount of ribose nucleic acid, and it is suggested that during growth the large granules are built up by the addition of protein (including enzymes) around the small particles. J. Elkes described his work on the X-ray diffraction patterns of nerve preparations under different conditions; and A. C. Fraser reported on histochemical investigations of fat absorption, using the whole rat intestine.

In Section VIII, Roughton, Haurowitz and George each discussed the physico-chemical reactions of hæmoglobin in relation to its structure. The type of arrangement of polypeptide chains within the protein part of the molecule was indicated by Perutz as a result of his X-ray and optical work. B. Chance gave the results of work on the mechanism of action of the hæm enzymes using the extremely fast spectroscopic flow method which he has developed. Theorell reported on the rate of appearance of isotopic iron in cytochrome $c$, catalase and peroxidase. A fruitful collaboration between Australia (R. Lemberg and Rawlinson) and London (Rimington and his colleagues) concerned the detailed structure of the hæm of cytochrome $a$. Tsou spoke on the properties of cytochrome $c$, in which the protein part of the molecule was reduced to a fraction of its former size with the hæm still attached, and E. C. Slater dealt with the mechanism of oxidation of co-enzyme I through the cytochrome system. K. G. Paul discussed the hæm links in cytochrome c. C. G. Holmberg and C. B. Laurell have isolated a copper protein, cæruloplasmin, from human and pig serum. D. Fox discussed the carotenoids of marine animals, and G. Wald described the chemical reactions initiated 
by the action of light on rhodopsin; the conversion of retinene to vitamin $A_{1}$ needs reduced co-enzyme $\mathrm{I}$.

In a joint session with Section III, Davies considered the experimental data on acid secretion obtained from isolated gastric mucosa and (with Ogston) a theory of the mechanism. C. Terner discussed the role of the back diffusion of hydrogen ions in the regulation of gastric acidity.

In Section IX, sessions were held on progesterone metabolism, steroid metabolism, hormones and carbohydrate metabolism, the pituitary gland and (with Section V) on the thyroid gland. C. H. Li and Henly, Morris andMorris discussed the chemistry of the adrenocorticotrophic hormone, and $\mathrm{Li}$ also its effects on glycogenesis in isolated diaphragm. C. A. Villee described the metabolism (with and without insulin) of carbon-14 labelled glucose by rat diaphragm in vitro, using nomal and diabetic animals with and without removal of adrenals or hypophysis or both. Cotes, Reid and F. G. Young considered the relation between growth-promoting pituitary extracts and experimental diabetes. G. Pincus discussed the blood and urine indices of human adrenal cortex function, and described the response to stress and to adrenocorticotrophic hormone in normal, psychoneurotic and schizophrenic subjects.

In Section $\mathrm{X}$ the necessity for a protein component in antigen formation was the subject of much discussion. The great technical difficulties in purification of natural antigens came out strongly in the communication of $M$. Loveless, and M. Heidelberger directed attention to the necessity for accurate methods of estimation of components of immunolo. gical systems In the session on drug resistance, there was discussion of development of resistance in tubercle bacilli to streptomycin (Hart; Trefouël Schaeffer); and of malarial parasites to 'Paludrine' and sulphadiazine (Bishop). Slonimski outlined studies on the production of mutant strains of yeast by exposure to acriflavine. $R$. Wurmser gave a mathematical and physicochemical presentation of the reactions involved in hæmagglutination. The nature of the antibody-antigen reaction (Marrack; Haurowitz) was the subject of prolonged discussion.

In the plant biochemistry section, symposia were held on starch, on cell-wall constituents and on photosynthesis. K. H. Meyer discussed amylose and amylopectin, phosphorylase and iso-phosphorylase. S. Peat and E. J. Bourne described a different amylopectin system, the Q-enzyme. A. FreyWyssling showed electron micrographs of cell walls. The hemi-cellulosic fractions of cell-wall polysaccharides were discussed by Isherwood and lignin structure by H. Erdtmann, by K. Kratzel and by F. F. Nord. R. Hill recounted the identification of two new cytochrome components from the chloroplasts. H. Gaffron and M. Calvin discussed the paths by which carbon-14 labelled carbon dioxide passes in the early stages of photosynthesis; a water-soluble fraction containing the labelled carbon appears after a few seconds of photosynthesis. The results of E. C. Wassink strongly suggested a role of phosphate bond energy in photosynthesis.

In Section XII much consideration was given to the production of penicillin, streptomycin and polymyxin E. Of particular interest was the occurrence of phage infection of Streptomyces griseus described by W. L. Koerber. Various aspects of brewing, of yeast production and a number of bacterial fermentations were discussed.

\section{THE GAP BETWEEN SCIENCE AND INDUSTRY 22/2}

$T$ HE discussion on September 5 in Section G (Engineering) of the British Association which followed Sir Arthur Bleming's presidential address to the Section. of Kridging the Gap between Science and Indqstry' Mike so many present-day discussions, centre lafyef on the question of staff. Sir Arthur had enthasized that the rate of industrial

ofads on both the acquisition of and its effective knowledge Most speeches in the discussion wer the question of the effective use, whether of new or of old knowledge, and of the dependence of this upon not merely the scientific or technical but also the managerial staff. Sir Andrew McCance, who opened the discussion, believes that the most serious question is the time taken for ideas already known and accepted by the scientific world to penetrate into that of industry and win acceptance and application. While this may be only a temporary phase, it will persist until every manager receives some technical training before he enters industry and until every scientific worker realizes that in management there is a skill which must be learned like every other skill. Sir Andrew considers that specialization is a main cause of the sluggishness with which scientific methods have been applied to British industry; but he also mentioned one industry in which more than four hundred firms between them employ on their staffs fewer than twenty technically
trained men.

Wing-Commander T. R. Cave-Browne-Cave picked up Sir Arthur Fleming's point about the importance of teaching staffs of universities and technical colleges having greater opportunities for maintaining contact with changing industrial practice. He agreed that university lecturers should have effective contact with the real problems of industry for which they are training their students; but no suggestion was advanced in the discussion as to how this is to be achieved, nor was the remark made in the recent Nuffield College report on the giving of technical training within industry rather than before entry put forward in discussion. Wing-Commander Cave. Browne-Cave is sceptical as to the ability of the universities to develop successfully the all-important characteristics of understanding and personality. Mr. J. R. Clarke considers that from the point of view of staffing industry with men trained in science and of receptive minds, those who have had a general rather than an honours or special degree are often more promising material; but the prospects which industry could offer such men if they enter it as technicians required consideration. Dr. E. Marsden, referring to Sir Arthur's observations on the differences between conditions in Great Britain and in the United States, thinks that our industry is organised too much for static conditions instead of for progressive change. The difference between British and American industry in this respect is not a matter of facilities but of method and outlook, and can only be changed by getting men of the right type and of initiative to enter industry.

Dr. B. J. A. Bard, however, laid the chief stress not so much on men as on materials. We have to remember the essential purpose of industrial research, and while the personal qualities of the scientific worker are of vital importance, industrial development in the main comes from the relentless pursuit 